\title{
EFFICIENCY TEST OF COLIMATOR SHUTTER AT THE X RAY TUBE IN RADIODIAGNOSTIC LABORATORY OF POLTEKKES JAKARTA 2 AND TWO CLINICAL HOSPITALS IN JAKARTA
}

\author{
Gando Sari, Sriyatun, Gita Putri Wahyuni \\ Jurusan Teknik Radiodiagnostik dan Radioterapi Politeknik Kemenkes Jakarta II \\ Jln. Hang Jebat III Blok F3 Kebayoran Baru DKI Jakarta, Kode Pos 12120
}

Email : bundagandosari@gmail.com

\begin{abstract}
The purpose of this study was to determine the efficiency of the collimator shutter with the presence or absence of leakage from the collector slit of the x-ray equipment.The type of research used is qualitative method using descriptive cross sectional method, conducting collimatory slot testing against x-ray equipment in laboratory and two installation of Radiology field of clinical practice for student of Radiodiagnostic and Radiotherapy of PoltekkesKemenkes Jakarta II.Result, there was a leakage of collimation shutter with marked blackening on x-ray film, on 8 (eight) x-ray equipment, there was a full leakage (very significant), and there was a big leak, and there was a slight leakage. Conclusion, in this research there is one $\mathrm{x}$-ray equipment according to the standard reference (golden standard), set by Permenkes No. 1250 / Menkes / SK / XII / 2009 that is SH x-ray equipment in Y hospital.
\end{abstract}

Keywords: shutter, collimation, Permenkes No. 1250 / Menkes / SK / XII / 2009, equipment, x-ray

\section{UJI EFISIENSI CELAH (SHUTTER) KOLIMASI TABUNG SINAR-X DI LABORATORIUM JUR TRO POLTEKKES JAKARTA II DAN DUA INSTALASI RADIOLOGI LAHAN PKL DI JAKARTA}

\begin{abstract}
ABSTRAK
Tujuan penelitian ini untuk mengetahui efisiensi shutter kolimator dengan ada tidaknya kebocoran dari celah kolimator peralatan sinar x.Jenis penelitian yang digunakkan adalah metode kualitatif dengan menggunakan metode deskriptif cross sectional, melakukan pengujian celah (shutter) kolimator terhadap peralatan sinar-x yang terdapat di laboratorium dan dua instalasi Radiologi lahan PKL mahasiswa Teknik Radiodiagnostik dan Radioterapi PoltekkesKemenkesJakarta II. Hasil diperoleh adanya kebocoran shutter kolimasi dengan ditandai adanya penghitaman pada film rontgen, pada 8 (delapan) peralatan sinar-x, ada yang kebocorannya menyeluruh (sangat signifikan), dan ada yang kebocorannya cukup besar, serta ada yang kebocorannya sedikit. Kesimpulan, padapenelitian ini terdapat satu peralatan sinar-x yang sesuai dengan acuan standar (golden standart),yang ditetapkan oleh Permenkes No. 1250/Menkes/SK/XII/2009 yaitu peralatan sinar-x merk SH di RS Y
\end{abstract}

Kata kunci :shutter, kolimasi , Permenkes No. 1250/Menkes/SK/XII/2009, peralatan , sinar x 


\section{PENDAHULUAN}

Dalam dunia kesehatan, penggunaan sinar- $x$ memiliki manfaat yang besar, terutama untuk menegakan diagnosa suatu penyakit. Disamping manfaatnya yang besar sinar- $\mathrm{x}$ juga memiliki efek yang merugikan bagi kesehatan tubuh apabila dosis radiasi yang diterima oleh tubuh cukup besar(1)

Tabung sinar- $\mathrm{x}$ merupakan tempat dihasilkannya sinar-x dari adanya perbedaan potensial yang tinggi antara katoda dan anoda(1)'(2), pada bagian luar tabung sinar- $x$ terdapat perangkat keras pembatas radiasi canggih yang akan digunakan, disebut kolimator. Kolimator merupakan alat pembatas radiasi yang umumnya digunakan pada radiografi, yang terdiri dari dari dua set penutup (shutter) timbal atau lempengan yang saling berhadapan dan bergerak dengan arah berlawanan secara berpasangan(1)'(3). Lempengan ini terletak 3 sampai 7 inchi di bawah tabung sinar $\mathrm{x}$. Pembatas yang dilakukan dengan penggunaan kolimator disebut sebagai collimation atau kolimasi.(4)

Pada peralatan sinar-x perlu adanya pengawasan dan kalibrasi secara rutin dan berkala untuk mengetahui apakah peralatan tersebut memang benar benar aman untuk digunakan atau tidak,sebagai salah satu bagian dari kendali mutu/ Quality Control (5).

Salah satunya keakuratan sebuah kolimator haruslah selalu dicek secara berkala sebagai tindakan kendali mutu untuk meningkatkan mutu dari sebuah pelayanan kesehatan(1,5)dan proteksi radiasi juga diperhatikan untuk tercapainya keselamatan dan kesehatan bagi pekerja,masyarakat dan lingkungan berdasarkan ICRP No.60 tahun 1990 yang telah diperbaharui menjadi ICRP No.103 tahun 2007.

Kegiatan yang mengunakan paparan radiasi harus ditekan serendah mungkindengan mempertimbangkan faktor ekonomis dan sosial di sebut ALARA atau As
Low As Reasonably Achievable, semua komponen dalam program disusun dan direncanakan sebaik mungkin dan memperhitungkan biaya yang dapat di pertanggungjawabkan secara ekonomis(6). Nilai Batas Dosis (NBD) radiasi bertujuan untuk meningkatkan keselamatan bagi pekerja radiasi,pasien dan masyarakat.(7)dan mencegah terjadinya efek deterministik yang membahayakan dan mengurangi terjadinya efek stokastik serendah mungkin. $(7,8)$

Suatu instansi ataupun rumah sakit yang mempunyai fasilitas radiologi harus memiliki izin legalitas yang sesuai dengan Peraturan Pemerintah Republik Indonesia No.29 Tahun 2008 tentang Perizinan Pemanfaatan Sumber Radiasi Pengion dan Bahan Nuklir(9)

Sesuai dengan Peraturan Kepala (PERKA) BAPETEN No. 9 Tahun 2011 tentang Uji Kesesuaian pesawat Sinar-X Radiologi Diagnostik dan Intervensional, Pasal 5, kolimasi merupakan salah satu parameter yang harus diuji dan merupakan salah satu parameter utama uji kesesuaian. Maksud dari parameter utama ini adalah parameter yang secara langsung mempengaruhi dosis radiasi pasien dan menentukan kelayakan operasi pesawat Sinar-X. $(10,11)$

\section{METODE PENELITIAN}

Penelitian ini dilakukan di laboratorium Jurusan Teknik Radiodiagnostik dan Radioterapi Poltekkes Kemenkes Jakarta II dan dua Instalasi Radiologi Lahan PKL mahasiswa, yaitu Instalasi Radiologi RS X dan Instalasi Radiologi RS Y dengan menggunakan teknik porposive dengan sampel uji efisiensi celah (shutter) kolimator peralatan sinar- $x$ di laboratorium Jurusan Teknik Radiodiagnostik dan Radioterapi Poltekkes Kemenkes Jakarta II dan serta dua instalasi radiologi RS lahan PKL mahasiswa Jurusan Teknik Radiodiagnostik dan 
Radioterapi Poltekkes Kemenkes Jakarta II, sebanyak 8 peralatan sinar-X.

Pengolahan data disajikan dengan deskriptif. Jika tidak terdapat gambaran hitam pada film,makacelah (shutter) kolimator telah sesuai dengan aturan. Tetapi jika terdapat

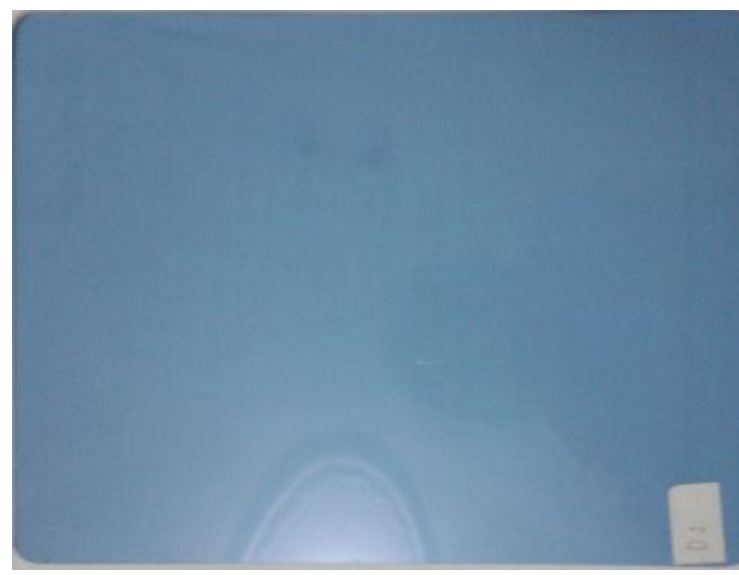

Gambar 1. Standar acuan (golden standart) hasil uji celah (shutter) kolimator pada sinar- $\mathrm{X}$

gambaran hitam pada film, maka telah terjadi kebocoran radiasi dan ketidak sesuaian pada pengaturan celah(shutter) kolimator peralatan sinar- $\mathrm{X}$.

Standar acuan(Golden standart) dari hasil pengujian celah (shutter) kolimator sesuai dengan PERMENKES RI nomor 1250/MENKES/SK/XII/2009(12) dengan hasil tidak ada kebocoran sinar-x pada film yang ditandai dengan hasil gambaran film bening atau tidak ada penghitaman seperti pada Gambar 1

\section{HASIL DAN PEMBAHASAN}

Hasil penelitian ini berupa data deskriptif yang di uji di tiga tempat. Jumlah peralatan sinar $\mathrm{x}$ yang digunakan pada uji efisiensi shutter kolimator ini sebanyak delapan unit, yang mana dua unit peralatan sinar-x dari laboratorium Jurusan TRO, empat unit peralatan sinar-x dari instalasi RS X dan dua unit peralatan sinar-x dari instalasi RS Y.

\section{Pungujian Shurter di Laboratorium Jurusan TRO}

Hasil pengujian celah shurter di Laboratorium jurusan TRO pada Peralatan Sinar-x Merk RD (Gambar 2A) menunjukan shutter kolimator tidak berfungsi dengan baik, terlihat dengan adanya kebocoran pada sisi transversal dengan ukuran $14 \mathrm{~cm}$, sedangkan sisi longitudinalnya berfungsi dengan baik.

Hasil Pengujian celah (shutter) Kolimator Peralatan Sinar-x Merk SH (Gambar 2B) menunjukan shutter kolimator tidak berfungsi dengan baik, terlihat dengan adanya kebocoran yang tidak merata pada sisi longitudinal dengan ukuran $8 \mathrm{~cm}$, dan terjadi pergeseran ke arah bucky tray sebesar $2,5 \mathrm{~cm}$, sedangkan sisi transversalnya berfungsi dengan baik.

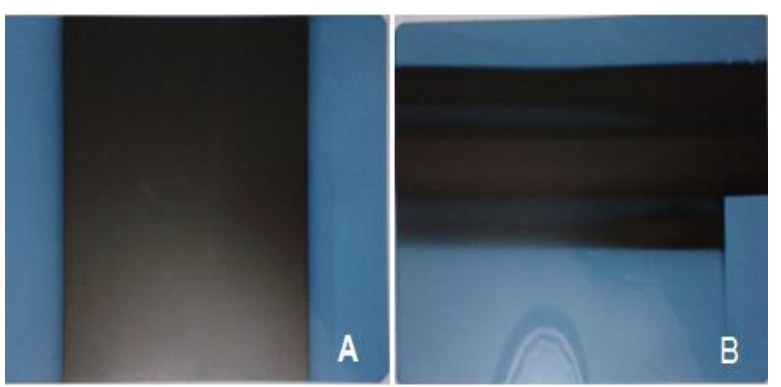

Gambar 2. Hasil Uji Shutter di Laboratorium TRO A) Peralatan Sinar-x merk RD B) Merk SH

\section{Pengujian Shutter di Rumah Sakit X}

Hasil Pengujian Shutter Kolimator Peralatan Sinar-x Merk SM-m (Gambar 3A) menunjukkan shutter kolimator tidak berfungsi dengan baik, terlihat dengan adanya kebocoran pada sisi transversal dengan ukuran $2,3 \mathrm{~cm}$, sedangkan sisi 
longitudinal ada kebocoran tidak merata dengan ukuran $3,5 \mathrm{~cm}$.

Hasil Pengujian Shutter Kolimator Peralatan Sinar-x Merk SM-s ( Gambar 3B) menunjukan shutter kolimator tidak berfungsi

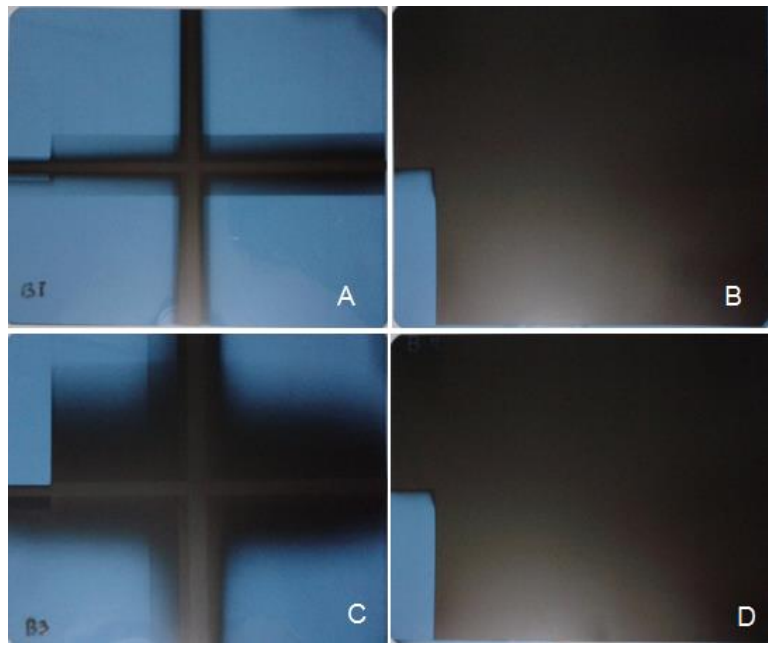

Gambar 3. Hasil Uji Shutter di RS-X A) Peralatan Sinar-x Merk SM-m B) Merk SM-s C) Merk SM-p D) Merk SM-g

dengan baik, terlihat dengan adanya kebocoran menyeluruh pada sisi transversal dan longitudinal.

Hasil Pengujian Shutter Kolimator Peralatan Sinar-x Merk SM-p ( Gambar 3C) menunjukan shutter kolimator tidak berfungsi dengan baik, terlihat dengan adanya kebocoran tidak merata pada sisi transversal dengan ukuran $4,5 \mathrm{~cm}$ dan sisi longitudinal $10,5 \mathrm{~cm}$.

Hasil Pengujian Shutter Kolimator Peralatan Sinar-x Merk SM-g (Gambar 3D) menunjukkan shutter kolimator tidak berfungsi dengan baik, terlihat dengan adanya kebocoran menyeluruh pada sisi transversal dan longitudinal.

\section{Pengujian Shutter di Rumah Sakit Y}

Hasil Pengujian Shutter Kolimator Peralatan Sinar-x Merk SH (Gambar 4A) menunjukan shutter kolimator berfungsi dengan baik, terlihat dengan tidak adanya kebocoran pada kedua sisi transversal dan longitudinal.

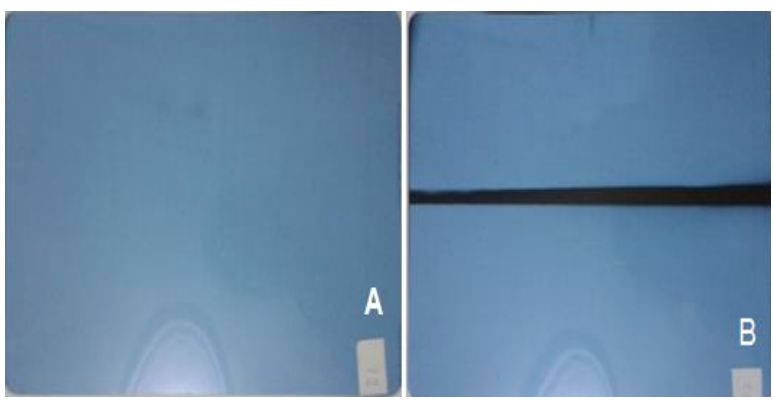

Gambar 4. Hasil Uji Shutter di RS-Y A) Peralatan Sinar-x Merk SH B) Merk SM

Hasil Pengujian Shutter Kolimator Peralatan Sinar-x Merk SM (Gambar 4B) menunjukan shutter kolimator tidak berfungsi dengan baik, terlihat dengan adanya kebocoran sedikit pada sisi longitudinal dengan ukuran $0,8 \mathrm{~cm}$.

Dari penelitian ini didapatkan hasil yang beragam, mulai dari shutter kolimator yang berfungsi baik yaitu yang tidak mengalami kebocoran sama sekali, hingga yang kurang berfungsi dengan baik yaitu yang mengalami kebocoran.Hasil yang menunjukan shutter kolimator berfungsi dengan baik, ditandai dengan tidak adanya kebocoran atau penyimpangan yang ditandai tidak terdapatnya gambaran hitam pada film yang telah dieksposi dan juga telah dilakukan prosessing film sesuai dengan standar acuan (golden standart) dari hasil pengujian celah (shutter) kolimator sesuai PERMENKES RI nomor 1250/MENKES/SK/XII/2009.

\section{SIMPULAN}

Hasil penelitian ini menunjukan dari 8 peralatan sinar $\mathrm{x}$, terdapat satu peralatan sinar-x yang sesuai dengan acuan standar (golden standart),yang sesuai dengan standar 
yang ditetapkan oleh Permenkes No. 1250/Menkes/SK/XII/2009 yaitu peralatan sinar-X merk SH di RS Y.

\section{DAFTAR PUSTAKA}

1. Carlton R. \& AM. Principle of Radiographic Imaging. New York: Delmar Publicer; 2002.

2. Soekardjo M. Kajian Uji Kesesuaian Pesawat Sinar- X di Instalasi Radiologi. 2015;79-82.

3. Curry TS. Dowdey JE. \& Murry RC . Christensen's Physics of Diagnostik Radiology. 4th ed. Philadelphia: Lippincott Williams \& Wilkins; 1990.

4. Fauber TL. Radiographic imaging \& Exposure. 3rd ed. St Louis: Mosby, 2009

5. NRCP Report No.99. Quality Assurance For Diagnostic Imaging. Bethesda; 1995.

6. Peraturan pemerintah no. 63. Keselamatan dan Kesehatan terhadap radiasi pengion. jakarta; 2000.
7. International Commision Radiation Protection(IRCP) No.103. Nilai Batas Dosis (NBD). 2007.

8. Akhadi Mukhlis. Dasar-dasar Proteksi Radiasi. Jakarta: PT Rineka Cipta; 2000.

9. BATAN. Peraturan Pemerintah Republik Indonesia Nomor 29 Tahun 2008 tentang Perizinan Pemanfaatan Sumber Radiasi Pengion dan Bahan Nuklir. 2008;(2).

10. BAPETEN. Uji Kesesuaian Pesawat Sinar-X Radiologi Diagnostik dan Intervensional. 2011;

11. Chesney DN \& MO Radiographic Imaging. London: CBS Publicer; 2005.

12. Keputusan Menteri Kesehatan Republik Indonesia Nomor 1250/MENKES/SK/XII/. Pedoman Kendali Mutu (Quality Control) Peralatan Radiodiagnostik. Jakarta; 2009. 